\title{
Agropopulations of Trifolium hybridum (Fabaceae) on the coal mining spoils in the forest-steppe of the Kuznetsk basin
}

\author{
Natalia Sheremet $^{1 *}$, Tatyana Lamanova ${ }^{1}$, and Vladimir Doronkin ${ }^{1}$ \\ ${ }^{1}$ Central Siberian Botanical Garden, SB RAS, 630090 Novosibirsk, Russia
}

\begin{abstract}
The agropopulations of Trifolium hybridum L. were studied in the agricultural phytocenoses established on the levelled coal mining spoils in the Kuzbas mining region (West Siberia, Russia). The clover was found to last in such agrophytocenoses for more than 20 years, whereas in agricultural phytocenoses on the zonal soils it lasted usually for 5-8 years. All studied communities were dominated by virginal and young generative plants. The optimal conditions for the clover growth and development in the disturbed areas were observed in the mixed (legumes and grasses) agrophytocenosis on the hydraulic dump. For the first time T. hybridum was found to be a species perspective for restoring vegetation cover in areas disturbed by open coal mining.
\end{abstract}

\section{Introduction}

The Kuznetsky coal basin is one of the biggest coal basins in Russia according to the amount of coal storage and production. The combinations of open coal mining pits and spoils occupy huge areas in the region. Currently spontaneous revegetation is the main approach to restore the disturbed lands. However, the quality of such restoration of plant cover needs seed input from the areas occupied by natural vegetation; such areas in the region are small and decreasingly diminishing. Therefore studies, focusing on mitigating environmental contamination by using new perspective plant species, are increasingly relevant. The T. hybridum L. species was for the first time tested for its potential to contribute to plant cover restoration of coal mining spoils in the Kuzbas. Multifaceted positive effect of clovers in agricultural phytocenoses established of coal mining spoils was registered in some studies $[1,2,3]$, the species productivity was not estimated.

The aim of our work was to study specifics of the $T$. hybridum development of agropopulations on the levelled coal mining spoils in the Kuznetsk regions. The species is a perennial or biennial herbaceous mono- or dicarpic plant with sympodial shoot growth [4, 5]. The plant usually grows $30-80 \mathrm{~cm}$ high. The core root can reach $2-3 \mathrm{~m}$ deep, but the main portion of roots can be found within the to $40-50 \mathrm{~cm}$ thick top layer. The flowering period is from mid June till September. The species is not very demanding in terms of soil properties, preferring, however, rather structured clay, loamy and sandy soils. It can survive

* Corresponding author: $\underline{\text { nsheremet } @ \text { yandex.ru }}$ 
under acidic $\mathrm{pH}$ of 4-5 and grow in mires, forming nodules even in such environment [6, 7]. It is a hygrophilous plant, able to endure low temperatures.

The species is widely spread in the European part of Russia, in Siberia, the Caucasus and the Far East of the country. It tastes somewhat bitter, therefore on the range and in the hay cattle consume it less actively as compared with $T$. pratense and $T$. repens, but when mixed with grasses in the hay, it is consumed well. The species is a common component of seed mixtures for initiating meadows in lowland and floodplain areas.

\section{Methods and conditions of the study}

In the Kuznetsk basin Trifolium hybridum L. was sown on the terminated hydraulic dump of the Mohovsky coal mining pit near Leninsk-Kuznetsky (54.570 N, 86.359 E), and on the levelled coal mining spoils of the Listvyansky pit $(53.403 \mathrm{~N}, 86.570 \mathrm{E})$, located $15 \mathrm{~km}$ away from Novokuznetsk (Kemerovo region, Russia).

Hydraulic dump is a hydrotechnical construction for storing the subsoil and ground layers overlying coal deposits, by hydraulic mechanization. The overlying subsoil and ground layers are represented by potentially fertile loess loams. The accumulated temperature (over $10{ }^{\circ} \mathrm{C}$ ) sums near Leninsk-Kuznetsky exceeds $1.800-1.900{ }^{\circ} \mathrm{C} \cdot$ day, and annual precipitation ranges $350-450 \mathrm{~mm}$. Usually precipitation is enough for plant growth and development, with semi dry and short dry periods occurring in some years.

The Listvyansky coal mining spoils, where T. hybridum was grown, are composed of the Permian deposits, consisting of sandstone, soapstone and aleurolites. According to the categorization of the subsoils suitable for biological recultivation, given by the State reference... [10], the Quaternary deposits are potentially suitable, whereas the Permian deposits are poorly suitable for biological recultivation due to their unfavourable physical properties. Mechanical and chemical properties of the spoil substrates, as well as the chemical composition of their water extracts were characterized earlier by T.G. Lamanova, N.V. Sheremet [11]. The annual precipitation in the area ranges $450-600 \mathrm{~mm}$.

Perennial grasses and herbs were sown on the hydraulic dump in June 1989 and on Listvyansky coal mining spoil in July 1990. Seed mixture contained seeds of grasses [11] and meadow clover ( $T$. pratense L.) with an admixture $T$. hybridum seeds. The agrophytocenoses were monitored during 1990-1993 and 1998 on the hydraulic dump site and on the Listvyansky study site during 1991-2014.

On each study site every year, starting with the second one, in July-early August the aboveground phytomass was cut in four replicates to estimate its production and species composition of the latter. In addition, in 1990-1993 and 2000, 2013 ten subplots of $1 \mathrm{~m}^{2}$ were chosen to determine plant projective cover, density, age structure, the number of generative shoots of all the species, comprising the communities. The age state of the individuals of the species was established in compliance with the recommendations [4].

\section{Results}

The yields of $T$. hybridum aboveground phytomass sharply fluctuated from year to year, most likely due to its specific life cycle as well as with differential seed production and plant survival $\mathrm{n}$ different years. For instance, in the annually flooded, albeit for a short time, meadow in the Oka River floodplain, where environmental conditions favour the species growth and development, its phytomass yeilds over 10 years averaged $30-50 \mathrm{~g} / \mathrm{m}^{2}$ in beneficial years, decreasing to almost 0 in between them [4].

In agrophytocenoses the hybrid clover is known to last usually for three years, sometimes for 5-8 years, reaching its maximal development on the second or third year 
[13]. In most regions of the former USSR territory it gives two yeilds. The first yield, averaged over several years and several regions, was $c a .350 \mathrm{~g} / \mathrm{m}^{2}$, whereas the second seasonal yeild was evaluated as $100-120 \mathrm{~g} / \mathrm{m}^{2}$.

Our studies showed that the optimal conditions for the species growth and development were on the hydraulic dump site due to increased water content of the soil substrate. If we use $10 \%$ of the total aboveground phytomass as a criterion for dominance, then the hybrid clover was found to be a codominant only once, i.e. on the 4th year of the mixed agrocenosis development. Its averaged over five years air-dried aboveground phytomass at the hydraulic dump site was $18 \pm 8 \mathrm{~g} / \mathrm{m}^{2}$, ranging $0.1-45 \mathrm{~g} / \mathrm{m}^{2}$.

We found that the hybrid clover in the agrophytocenoses may last for more than 20 years. At the Listvyansky coal mining spoils where the increased seed sowing rate was used, the species was observed on the 15th year of agrophytocenoses development, contributing $3 \%$ of the air-dried total aboveground phytomass while mixed with grasses, and $1 \%$ while mixed with the meadow clover on the 24 th year of development, and $2.9 \%$ on the 13th year while mixed with grasses and Onobrychis arenaria (Kit.) DC. The airdried T. hybridum aboveground phytomass ranged $0-10 \mathrm{~g} / \mathrm{m}^{2}$ in the clover+grasses mixture with increasing seed sowing rate, $0-4 \mathrm{~g} / \mathrm{m}^{2}$ and $0-13 \mathrm{~g} / \mathrm{m}^{2}$ when in combination with the meadow clover or the Siberian sainfoin, respectively.

The T. hybridum projective cover and density at the hydraulic dump site were found to reach their maxima on the 4th year of the agrophytocenosis development, whereas at Listvyansky coal mining spoil the respective maxima were reached on the $2^{\text {nd }}$ year in the mixed clover and grasses agrocenosis established with the increased seed sowing rate.

The ontogenetic and seasonal rhythms of the hybrid clover in the floodplain meadows of the Oka River were described by N.P. Krylova [4], who distinguished the following age stages of the plants: shoots, juvenile, immature, mature vegetative, generative and senile plants.

At the hydraulic dump site we found immature, virginile, young generative and middle age generative individual plants, dominated by virginile and young generative ones. The young generative clover plants also prevailed on the Listvyansky spoils. The plants at postgenerative staged (subsenile and senile) were not found in those agrophytocenoses. The apparent absence of plants at this age stage in T. hybridum cenopopulations was found by T.M. Pokrovskaya in the Moscow region [13].

The published information concerning the transition of the hybrid clover to the generative stage is rather controversial. Sometimes it occurred on the second year or even in autumn of the first [12], or on the third year [4]. Fertilization and early harvesting was found to bring the maximal reproductive intensity happened on the third year, when up to seven generative shoots were produced; wet and cool years were shown to bring the reproductive maximum on the fourth year, when 4-6 generative shoots (in some individuals even 13-16 shoots) were formed. In dry years the individual plants at the 4th year of growth were found to produce two generative shoots.

On the coal mining spoils individual clover plants were found to transit into the generative stage on the second year of growth. The rapid transition of plants from the juvenile to the mature adult state, i.e. the fast development of clover plants under specific environmental conditions, confirms fast population development. The more similar the environmental conditions are to the ecological optimum of the species, the more the relative abundance of the generative plants in the population is. The number of generative shoots was found to reach its maximum in the same year, ranging from 7 to 37 shoots per plant at the hydraulic dump site and from 5 to 1337 shoots per plant at the Listvyansky coal mining site.

The height of the wild-growing hybrid clover plants is $15-60 \mathrm{~cm}$, whereas the height of its cultivars varies from 40 to $100 \mathrm{~cm}$ [14]. In the agropopulations on Technosols in the 
Kuzbas the species generative shoots were found to reach, albeit rarely, $80 \mathrm{~cm}$ in height, averaging 25-40 cm (Table).

Table 1. Some properties of agricultural populations of T. hybridum on the levelled coal mining spoils in the forest steppe zone of the Kuznetsk basin (mean \pm a.e. and «lim» as fluctuation range)

\begin{tabular}{|c|c|c|c|c|}
\hline $\begin{array}{c}\text { Year of } \\
\text { observation } \\
\text { (year of plant } \\
\text { ontogenesis) }\end{array}$ & $\begin{array}{c}\text { Projective cover, } \\
\%\end{array}$ & $\begin{array}{c}\text { Number of } \\
\text { shoots, } \mathrm{pcs} / \mathrm{m}^{2}\end{array}$ & $\begin{array}{l}\text { Number of generative } \\
\text { shoots, } \mathrm{pcs} / \mathrm{m}^{2}\end{array}$ & $\begin{array}{l}\text { Height of the } \\
\text { generative shoots, } \\
\mathrm{cm}\end{array}$ \\
\hline \multicolumn{5}{|c|}{ Quaternary deposits, hydraulic dump of the Mohovsky pit } \\
\hline \multicolumn{5}{|c|}{ Legumes and grasses mixture } \\
\hline 1990 (2nd) & $\begin{array}{c}6.5 \pm 4.5 \\
\lim 0-40\end{array}$ & $\begin{array}{l}2.2 \pm 1.4 \\
\lim 0-15\end{array}$ & $\begin{array}{l}12.3 \pm 8.2 \\
\lim 0-66\end{array}$ & $\begin{array}{l}41.9 \pm 15.9 \\
\lim 9.5-80\end{array}$ \\
\hline 1991 (3rd) & $\begin{array}{l}3.6 \pm 3.5 \\
\lim 0-35\end{array}$ & $\begin{array}{l}2.7 \pm 2.5 \\
\lim 0-26\end{array}$ & $\begin{array}{l}6.9 \pm 6.2 \\
\lim 0-64\end{array}$ & $\begin{array}{l}42.0 \pm 8.6 \\
\lim 20-59\end{array}$ \\
\hline 1992 (4th) & $\begin{array}{l}16.1 \pm 6.0 \\
\lim 0-45\end{array}$ & $\begin{array}{l}11.6 \pm 4.1 \\
\lim 0-34\end{array}$ & $\begin{array}{l}0.8 \pm 0.7 \\
\lim 0-6\end{array}$ & $\begin{array}{l}24.4 \pm 1.6 \\
\lim 15-35 \\
\end{array}$ \\
\hline 1993 (5th) & $\begin{array}{c}0.2 \pm 0.1 \\
\lim 0-0.5\end{array}$ & $\begin{array}{c}2.1 \pm 0.3 \\
\lim 0-2\end{array}$ & $\begin{array}{l}0.6 \pm 0.6 \\
\lim 0-6\end{array}$ & $\begin{array}{l}25.5 \pm 2.5 \\
\lim 23-28\end{array}$ \\
\hline \multicolumn{5}{|c|}{ Permian deposits, levelled coal mining spoils of the Listvyansky pit } \\
\hline \multicolumn{5}{|c|}{ Clover and grasses mixture, established by the increased seed sowing rate } \\
\hline 1991 (2nd) & $\begin{array}{c}17.8 \pm 10.7 \\
\lim 0-85\end{array}$ & $\begin{array}{c}20.2 \pm 12.5 \\
\lim 0-119 \\
\end{array}$ & $\begin{array}{c}33.1 \pm 33.1 \\
\lim 0-171 \\
\end{array}$ & $\begin{array}{l}21.1 \pm 0.8 \\
\lim 14-30 \\
\end{array}$ \\
\hline 1992 (3rd) & $\begin{array}{l}1.0 \pm 1.0 \\
\lim 0-10\end{array}$ & $\begin{array}{c}0.4 \pm 0.4 \\
\lim 0-4 \\
\end{array}$ & $\begin{array}{c}4.0 \pm 3.2 \\
\lim 0-40 \\
\end{array}$ & $\begin{array}{l}25.2 \pm 3.3 \\
\lim 16-30 \\
\end{array}$ \\
\hline \multicolumn{5}{|c|}{ Grasses mixed with T. pratense } \\
\hline 1992 (3-й) & $\begin{array}{c}0.2 \pm 0.1 \\
\lim 0-1.5 \\
\end{array}$ & $\begin{array}{c}0.4 \pm 0.3 \\
\lim 0-2\end{array}$ & $\begin{array}{r}2.4 \pm 1.8 \\
\lim 0-17 \\
\end{array}$ & $\begin{array}{l}37.0 \pm 2.4 \\
\lim 30-40\end{array}$ \\
\hline \multicolumn{5}{|c|}{ Grasses mixed with Onobrychis arenaria } \\
\hline 2000 (11th) & $\begin{array}{l}2.1 \pm 1.9 \\
\lim 0-20 \\
\end{array}$ & $\begin{array}{l}1.1 \pm 0.6 \\
\lim 0-5 \\
\end{array}$ & $\begin{array}{r}2.0 \pm 1.2 \\
\lim 0-10 \\
\end{array}$ & $\begin{array}{l}45.9 \pm 3.2 \\
\lim 20-60 \\
\end{array}$ \\
\hline
\end{tabular}

\section{Conclusions}

1. The hybrid clover life longevity in agricultural phytocenoses established on the levelled coal mining spoils in the forest-steppe zone of the Kuzbas region exceeds its longevity in similar communities established on zonal soils.

2. The hybrid clover on the coal mining spoils transits to the generative stage on the second year of life.

3. The optimal conditions for the species growth and development in the disturbed areas were observed in the mixed agrophytocenoses of legumes and grasses on the hydraulic dump.

4. For the first time the hybrid clover was shown to be a species perspective for restoring areas disturbed by the open coal mining in the Kuzbas region.

\section{References}

1. M. Gryndlera, R. Sudová, D. Püschel, J. Rydlová, M. Janoušková, M. Vosátka, Biores. Technol. 99, 6391-6399 (2008)

2. R. Tropek, M. Hejdac, T. Kadlec, L. Spitzer, Ecol. Eng. 57, 252-260 (2013) 
3. Y. Li, H. Wen, L. Chen, T. Yin, PLoS One, 9, 12, (2014), e115024

4. N.P. Krylova, The pink clover. In Biological flora of the Moscow region (Moscow, 1975) (in Russian)

5. A.P. Matveev, The hybrid clover (pink, Swedish) (Trifolium hybridum L.) Diagnoses and keys for age stages of the meadow plants (Moscow, 1963) (in Russian)

6. Fodder herbs and grasses (Saint-Petersburg, 1898) (in Russian)

7. A.S. Novoselova, Clover breeding and seed-farming (Moscow, 1986) (in Russian)

8. Clover in Russia (Voronezh, 2002) (in Russian)

9. Breeding and seed-farming of perennial herbs and grasses. (Moscow, 2005) (in Russian)

10. Federal standard GOST 17.5.3.05-84 Land recultivation. Nature and land protection (Moscow, 2002) (in Russian)

11. T.G. Lamanova, N.V. Sheremet, Agrophytocenoses on the coal mining spoils in the southern part of the Kuznetsk basin (Novosibirsk, 2010) (in Russian)

12. V.M. Ramenskaya, Perennial grasses and herbs in meadow-pasture crop rotation (Moscow, 1951) (in Russian)

13. T.M. Pokrovskaya, Biol. Sci. 2, 110 - 115 (1960) (in Russian)

14. R.G. Piskovatskaya, S.N. Cheprasova, A.P. Zhukov, E.V. Kapustina, Adaptive fodder production: problems and solutions (Moscow, Rosinformagrotech, 2002) (in Russian) 